\title{
IMPACTS OF DEFORESTATION ON WATER BALANCE COMPONENTS OF A WATERSHED ON THE BRAZILIAN EAST $\operatorname{COAST}^{(1)}$
}

\author{
Donizete dos Reis Pereira ${ }^{(2)}$, André Quintão de Almeida ${ }^{(3)}$, Mauro Aparecido Martinez ${ }^{(4)} \&$ \\ David Rafael Quintão Rosa ${ }^{(5)}$
}

\begin{abstract}
SUMMARY
The Brazilian East coast was intensely affected by deforestation, which drastically cut back the original biome. The possible impacts of this process on water resources are still unknown. The purpose of this study was an evaluation of the impacts of deforestation on the main water balance components of the Galo creek watershed, in the State of Espírito Santo, on the East coast of Brazil. Considering the real conditions of the watershed, the SWAT model was calibrated with data from 1997 to 2000 and validated for the period between 2001 and 2003. The calibration and validation processes were evaluated by the Nash-Sutcliffe efficiency coefficient and by the statistical parameters (determination coefficient, slope coefficient and $\mathrm{F}$ test) of the regression model adjusted for estimated and measured flow data. After calibration and validation of the model, new simulations were carried out for three different land use scenarios: a scenario in compliance with the law (C1), assuming the preservation of PPAs (permanent preservation areas); an optimistic scenario (C2), which considers the watershed to be almost entirely covered by native vegetation; and a pessimistic scenario (C3), in which the watershed would be almost entirely covered by pasture. The scenarios $\mathrm{C} 1, \mathrm{C} 2$ and $\mathrm{C} 3$ represent a soil cover of native forest of 76,97 and $0 \%$, respectively. The results were compared with the simulation, considering the real scenario (C0) with $54 \%$ forest cover. The NashSutcliffe coefficients were 0.65 and 0.70 for calibration and validation, respectively, indicating satisfactory results in the flow simulation. A mean reduction of $10 \%$ of the native forest cover would cause a mean annual increase
\end{abstract}

(1) Received for publication on October 30, 2013 and approved on May 14, 2014.

(2) Professor, Universidade Federal de Viçosa - UFV, Campus de Florestal. Rod. LMG 818, km 6. CEP 35690-000 Florestal (MG), Brazil. E-mail: doniagri@yahoo.com.br

(3) Professor, Universidade Federal de Sergipe - UFS. Av. Marechal Rondon, s/n, Jardim Rosa Elze. CEP $49100-000$ São Cristovão (SE), Brazil. E-mail: andreqa@gmail.com

(4) Professor, Universidade Federal de Viçosa - UFV. Av. P.H. Rolfs, s/n. CEP 36570-900 Viçosa (MG), Brazil. E-mail: mmauro@ufv.br

(5) Doctoral student in Agricultural Engineering, UFV. E-mail: davidquintao@gmail.com 
of approximately $11.5 \mathrm{~mm}$ in total runoff at the watershed outlet. Reforestation would ensure minimum flows in the dry period and regulate the maximum flow of the main watercourse of the watershed.

Index terms: SWAT, watershed management, hydrological modeling, Atlantic Forest.

\title{
RESUMO: IMPACTOS DO DESMATAMENTO NOS COMPONENTES DO BALANÇOHÍDRICODE UMABACIA NA COSTA LESTE BRASILEIRA
}

\begin{abstract}
A costa leste brasileira passou por vasto processo de desmatamento, reduzindo drasticamente seu bioma original. Os possiveis impactos desse processo sobre os recursos hidricos ainda são desconhecidos. Objetivou-se com este trabalho avaliar os impactos do desmatamento sobre os principais componentes do balanço hídrico da bacia hidrográfica do córrego do Galo, ES, localizada na costa leste do Brasil. Para as condições atuais da bacia, o modelo SWAT foi calibrado, no periodo entre 1997 e 2000, e validado, entre 2001 e 2003. Os processos de calibração e validação foram avaliados pelo coeficiente de Nash-Sutcliffe e pelos parâmetros estatísticos (coeficiente de determinação, coeficiente angular e teste F) da regressão ajustada entre a vazão medida e estimada. Depois do modelo calibrado e validado, novas simulações foram realizadas, considerando três cenários distintos de uso do solo: o legalmente ideal (C1), que leva em consideração a preservação em áreas de APPs; o otimista (C2), que considera a bacia em quase sua totalidade preservada por vegetação nativa; e o pessimista (C3), que considera a bacia coberta em quase sua totalidade por pastagem; o que corresponde a 76, 97 e $0 \%$ de cobertura florestal nativa. Os resultados foram comparados com a simulação realizada com o cenário atual (CO), com $54 \%$ da área coberta com floresta. Os valores de Nash-Sutcliffe foram de 0,65 e 0,70, na calibração e validação, respectivamente, indicando resultados satisfatórios na simulação da vazão. A redução em média de $10 \%$ da cobertura florestal nativa provaria aumento médio anual de aproximadamente $11,5 \mathrm{~mm}$ no escoamento total obtido na saida da bacia. O reflorestamento asseguraria as vazões mínimas do periodo de estiagem e regularizaria a vazão máxima do curso d'água principal da bacia.
\end{abstract}

Termos de indexação: SWAT, manejo de bacias, modelagem hidrológica, Mata Atlântica.

\section{INTRODUCTION}

Over the years, man has modified the original matrix of land use, converting entire biomes to other uses, mainly of agriculture. In Brazil, the original area of the Atlantic Forest biome has been drastically reduced, maintaining only $8 \%$ of the original cover (SOS, 2002). Any change in the original land use can result in significant alterations of the water balance components of a watershed. Hydrological modeling studies have demonstrated the impact of such changes on these components (Pires \& Costa, 2013). Changes in the processes of evapotranspiration, soil water infiltration and runoff are the main consequences of land use changes in watersheds.

The assessment of impacts on water resources is one of the most relevant applications of hydrological models, which are fundamental tools for the planning and management of a basin (Viola et al., 2009). Andrade et al. (2013) reported that the hydrological models can be applied to evaluate management strategies of water resources and the watershed response to periodic climatic variations, design floods, floods in real time, and land use changes.

Several hydrological models have been developed and applied in the simulation of the major water balance components, such as SWAT (Green \& van Griensven, 2008), SMAP (Saraiva et al., 2011), LASH (Beskow et al., 2011), AnnAGNPS (Yuan et al., 2011). The Soil and Water Assessment Tool (SWAT) is a semiconceptual, semi-distributed and continuous-time model, and was developed to predict the effects of different soil uses, covers and managements on water and sediment production and water quality (Durães et al., 2011). The model stands out among other hydrological models with wide utility and great flexibility in simulation. It was calibrated and used by several authors for hydrological simulations in several river basins in the world (Githui et al., 2009; Hörmann et al., 2009; Sexton et al., 2010).

The objective of this study was to evaluate the possible impacts of deforestation on the key water balance components in the Galo creek watershed on the East coast of Brazil based on SWAT model simulation.

\section{MATERIAL AND METHODS}

\section{Study area}

The catchment area of the Galo creek, with an area of $943 \mathrm{~km}^{2}$ (Figure 1a), is located in the eastern 

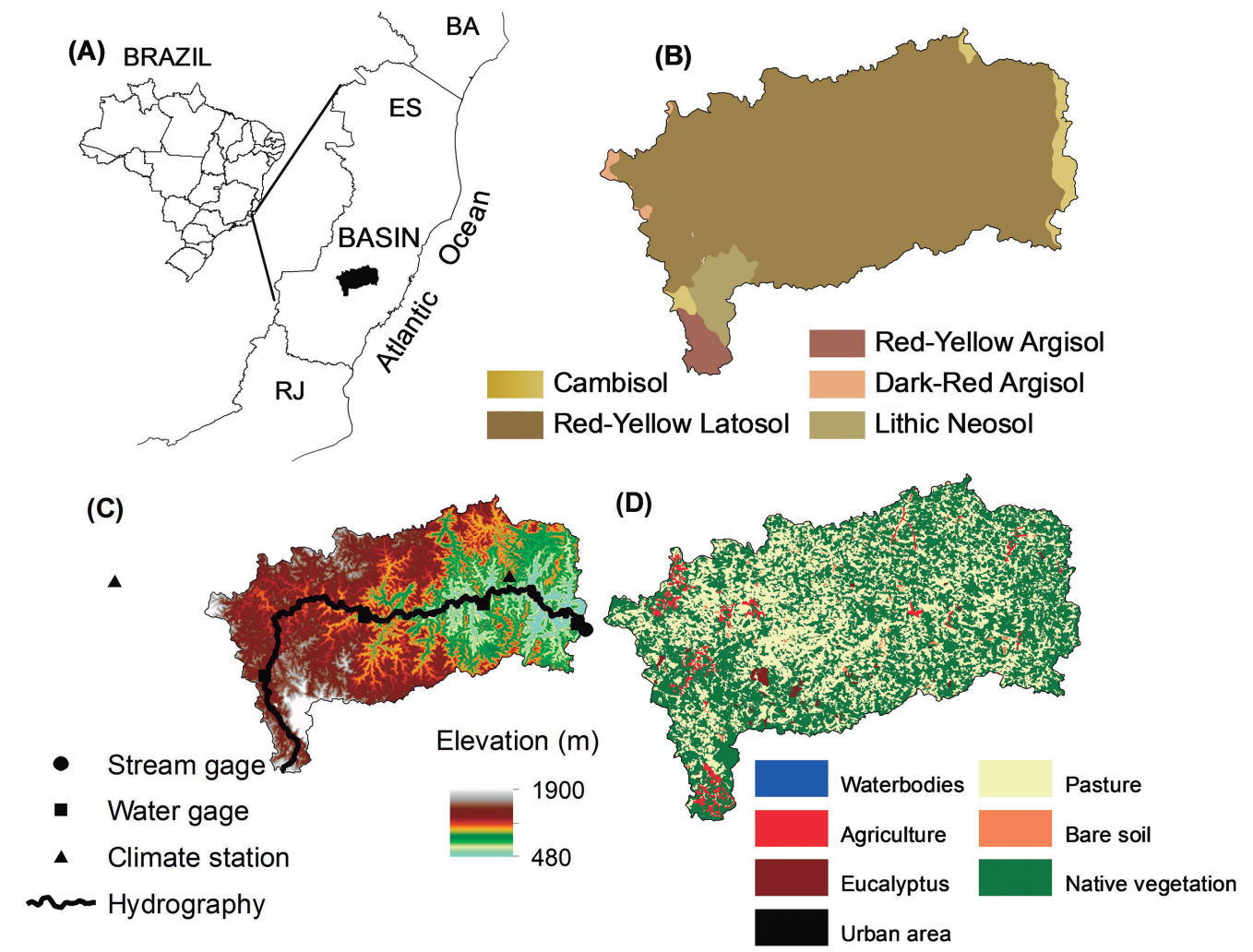

Figure 1. Map of localization (a), soil type (b), altitude (c), and land use and soil cover (d) of the Galo creek watershed.

part of Brazil, in the municipality of Domingos Martins, Espirito Santo (20 $\left.15^{\prime} \mathrm{S} ; 40^{\circ} 50^{\prime} \mathrm{W}\right)$, a mountainous region of the State.

The climate is Cwa, according to the Köppen classification, with dry winters and rainy summers, with a mean maximum temperature of $22{ }^{\circ} \mathrm{C}$ and mean minimum $18{ }^{\circ} \mathrm{C}$. The mean annual rainfall is approximately $1,250 \mathrm{~mm}$. The main soil types found in the basin (Figure 1b), according to the Brazilian soil classification system (Embrapa, 2006) are Red-Yellow Latosol (92 \%), Lithic Neosol (4.6\%), Cambisol (2.1\%), and Red-Yellow and Dark-Red Argisol (1.1\%).

\section{Water balance modelling}

The key water balance components of the basin were modeled daily with the SWAT model as follows:

$$
\mathrm{SW}_{\mathrm{t}}=\mathrm{SW}_{0}+\sum_{\mathrm{i}=1}^{\mathrm{n}}\left(\mathrm{P}_{\mathrm{i}}-\mathrm{Q}_{\mathrm{sup}_{\mathrm{i}}}-\mathrm{Q}_{\text {lat }_{\mathrm{i}}}-\mathrm{ET}_{\mathrm{i}}-\mathrm{Q}_{\text {sub }_{\mathrm{i}}}\right)
$$

where $\mathrm{SW}_{\mathrm{t}}=$ final water content of the soil, $\mathrm{mm} ; \mathrm{SW}_{0}$ = initial soil water content, $\mathrm{mm} ; \mathrm{P}_{\mathrm{i}}=$ pluvial precipitation, $\mathrm{mm}$; $\mathrm{Q}_{\text {suri }}=$ surface runoff, $\mathrm{mm} ; \mathrm{Q}_{\text {lati }}=$ lateral flow, $\mathrm{mm} ; \mathrm{ET}_{\mathrm{i}}=$ evapotranspiration, $\mathrm{mm}$; and $\mathrm{Q}_{\text {subi }}=$ groundwater flow, $\mathrm{mm}$.

The surface runoff was estimated by the modified curve method (Neitsch et al., 2005a) number. The lateral flow was estimated by the kinematic storage method. To simulate evapotranspiration, the model estimates water evaporation from the soil and plant transpiration separately; water evaporation from the soil is estimated by exponential functions of soil depth and water content; and transpiration is estimated by correcting the potential evapotranspiration (PET) according to the vapor pressure deficit and soil water content. The potential evapotranspiration was estimated by the Pennman-Monteith method (Monteith, 1965). The groundwater flow was estimated by separating the contribution of the shallow from the deep aquifer; the contribution of the shallow aquifer was considered in the water balance and that of the deep aquifer as system loss (Neitsch et al., 2005a).

\section{Input parameters of the SWAT model}

Three map types are needed as SWAT input data, i.e., maps of: soil type, topography and land use and soil cover of the basin (Figure 1). The 1:1,000.000 soil map was provided by the Brazilian Institute of Geography and Statistics (IBGE) (Figure 1b). The hydrophysical parameters of the soil were obtained from RADAMBRASIL (1983) for the soil profiles 18, 28, 29, 41, and 64. Hydraulic conductivity data of saturated soil obtained in field work by Moraes et al. (2003) and Zonta et al. (2010) were used as input values. The data related to groundwater flow and vegetation were obtained from the database of the proper model, with some changes in vegetation parameters (Table 1 ). 
Topographic data (Figure 1c) were obtained from the Hydrographically Conditioned Digital Elevation Model (HCDEM), based on 1:50,000 topographic maps of IBGE, according to the method proposed by Guedes \& Silva (2012). The land use was mapped (Figure 1d) from images of the Thematic Mapper (TM) sensor on Landsat-5, of 2005, with a spatial resolution of $30 \mathrm{~m}$. Initially, the spectral bands of the image were preprocessed and georeferenced, resulting in a mean square error of $8.5 \mathrm{~m}$. The classifier of land use mapping was supervised by Maximum Likelihood.

Other important input parameters of the SWAT model are hydro-climatic data such as rainfall ( $\mathrm{mm})$, maximum and minimum air temperature $\left({ }^{\circ} \mathrm{C}\right)$, solar radiation $\left(\mathrm{Mj} \mathrm{m}^{-2} \mathrm{~s}^{-2}\right)$, wind speed $\left(\mathrm{m} \mathrm{s}^{-1}\right)$, relative humidity (\%), and the flow of the watercourse $\left(\mathrm{m}^{3} \mathrm{~s}^{-1}\right)$. The meteorological data used as model input were extracted from two points on the grid of the Climatic Research Unit (New et al., 2000). Aside from these points, four rainfall stations distributed across the basin and a fluviometric station of the hydrometeorological network of the National Water Agency (ANA) at the basin outlet were used. All hydrometeorological data were used on a daily time scale.

\section{Model calibration and validation}

Daily flow data $\left(\mathrm{m}^{3} \mathrm{~s}^{-1}\right)$ of two periods (from Jan. $1^{\text {st }}, 1997$ to Dec. 31, 2000 and Jan. $1^{\text {st }}, 2001$ to Dec. $20,2003)$ were used for model calibration and validation. Both 1995 and 1996 were used as a warm up period of the model to establish the initial soil water conditions, which were verified after 1997 (Figure 2).

Calibration was performed by the trial-and-error method and the accuracy tested by the Nash-Sutcliffe efficiency $\left(\mathrm{E}_{\mathrm{NS}}\right)$ coefficient and linear regression analysis. The model accuracy based on the $\mathrm{E}_{\mathrm{NS}}$ coefficient was evaluated by the classification suggested by van Liew et al. (2007). According to the classification, value $\mathrm{E}_{\mathrm{NS}}=1$ means perfect fit of the data simulated by the model; $\mathrm{E}_{\mathrm{NS}}>0.75$ a suitable and good model; $0.36<\mathrm{E}_{\mathrm{NS}}<0.75$ that the model is satisfactory and $<0.36$ that it is unsatisfactory.

Table 1. Modified vegetation parameters from SWAT database for the hydrologic simulation in the Galo creek watershed

\begin{tabular}{lcccc}
\hline Land use & BLAI & GSI & RDMX & OV_N \\
\hline & $\mathrm{m}^{2} \mathrm{~m}^{-2}$ & $\mathrm{~m} \mathrm{~s}^{-1}$ & $\mathrm{~m}$ & $\mathrm{~s} \mathrm{~m}^{-3}$ \\
Native vegetation & $7.5^{(1)}$ & $0.017^{(3)}$ & $5.0^{(1)}$ & $0.30^{(4)}$ \\
Eucalyptus & $4.0^{(1)}$ & $0.010^{(1)}$ & $2.5^{(1)}$ & $0.12^{(4)}$ \\
Agriculture & $7.0^{(2)}$ & $0.014^{(5)}$ & $1.5^{(5)}$ & $0.19^{(4)}$ \\
Pasture & $3.0^{(2)}$ & $0.013^{(3)}$ & $0.6^{(2)}$ & $0.15^{(4)}$ \\
\hline
\end{tabular}

BLAI: maximum leaf area index; GSI: maximum stomatal conductance; RDMX: maximum root depth and OV_N: manning coefficient for the soil surface. ${ }^{(1)}$ Almeida \& Soares (2003);

${ }^{(2)}$ Viola et al. (2009); ${ }^{(3)}$ Sá et al. (1996); ${ }^{(4)}$ Neitsch et al. (2005 b);

(5) average value for different agricultural crops.

\section{Land use scenarios}

Once calibrated, new simulations were performed, considering three different land-use scenarios (Table $2)$. In the first scenario (C1), the permanent preservation areas (PPAs) of the basin were considered to be covered by native vegetation (Atlantic Forest). In the second (C2), the optimistic scenario, the largest possible percentage of the basin area was considered to be covered by native forest. In the third, the pessimistic scenario (C3), the largest possible percentage of the basin area was considered to be covered by grassland. In the end, the main components of the water balance simulation for the three scenarios were compared with the model simulation, considering the real land use (C0) of 2005. During the study years, land use and soil cover in the basin were not significantly changed (for further details, see Almeida et al., 2009).

In the first scenario (C1), four classes of permanent preservation areas were considered. They consisted of a radius of $50 \mathrm{~m}$ around springs, a strip of $30 \mathrm{~m}$ along the banks of watercourses, the upper third of hilltops and of slopes steeper than $45^{\circ}$, according to Conama (2002). The PPAs were defined based on the method developed by Peluzio et al. (2010), strictly according to the specifications of Art. 2 and 3, Resolution N. 303/2002, of Conama. In the PPA around water sources, circles (radius $50 \mathrm{~m}$ ) were drawn around the springs. It was considered that all rivers in the basin had a width of less than 10 and $30-\mathrm{m}$ wide bands were defined on either river bank. To outline the PPAs on the hilltops, the ratio of the hilltop height by the base for each HCDEM cell was estimated. This procedure identified all cells with a ratio equal to or greater than $2 / 3$. For areas with slopes greater than $45^{\circ}$, the HCDEM was reclassified, identifying the areas $>45^{\circ}$.

In the first simulation scenario, the permanent preservation areas were considered forest covered with

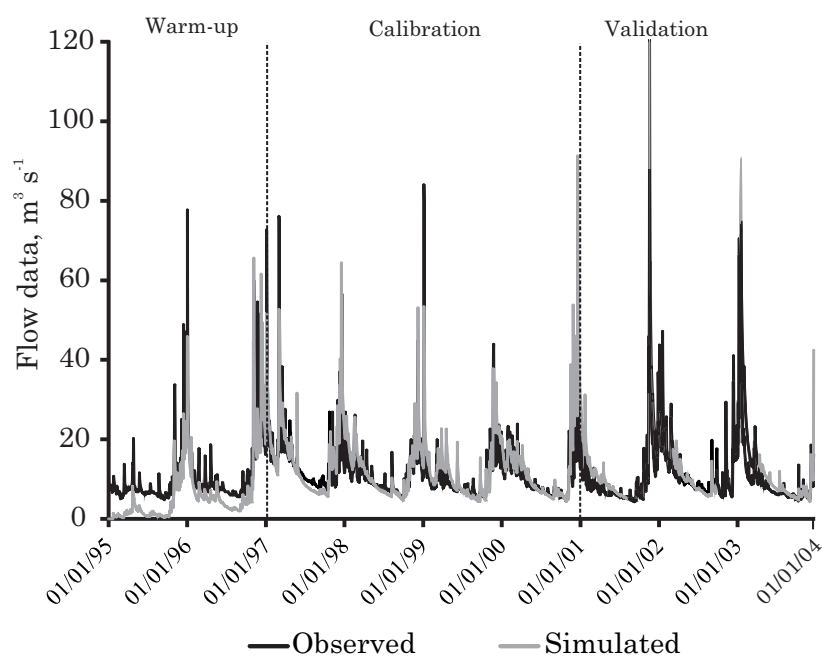

Figure 2. Warm up, calibration and validation periods of the SWAT model. 
Atlantic Forest biome. In the second simulation scenario, areas originally ( $\mathrm{C} 0$ ) covered by grassland (Figure 1d) were converted into native forest. In the third simulation scenario, areas currently occupied by Atlantic Forest (C0) (Figure 1d) were converted into pasture.

\section{RESULTS}

The observed and SWAT-simulated hydrographs of daily runoff and cumulative flow for the Galo creek watershed were compared (Figure 3) in calibration and validation periods.

The comparison between the hydrographs shows the fit between the hydrograph shapes and between the peak and base runoff, with some underestimates (Jan. 4, 1999) and overestimates (Nov. 17, 2001). This behavior of underestimating and overestimating peak values is common in hydrological modeling, due to the difficulties of representing the maximum flow after high rainfall events (von Stackelberg et al., 2007; Mello et al., 2008; Du et al., 2013). The comparison between the cumulative hydrograph showed that the model overestimated the runoff volume throughout the calibration and validation period, and that this overestimation was higher in the validation period (Figure 3b).

Table 3 shows the errors of cumulative runoff in the SWAT simulation. The errors of simulation of annual runoff in absolute values ranged from 0.6 to $30.4 \%$, over the entire analysis period. Errors in the same order of magnitude with the SWAT model were reported by von Stackelberg et al. (2007) in modeling the Tacuarembó River Basin in Uruguay.

The statistics of the regression model were fit to the measured and SWAT-simulated values (Table 4). The $\mathrm{F}$ and $\mathrm{T}$ tests (applied to parameter $\beta 1$ ) indicated that the linear regressions were significant at $5 \%$, i.e., the SWAT-simulated values did not differ statistically from those observed at the $5 \%$ significance level. The coefficients of determination $\left(\mathrm{R}^{2}\right)$ and Nash were 0.91 and 0.65 for the calibration and 0.92 and 0.70 for the validation period (Table 4). According to the criteria established by van Liew et al. (2007), the calibration and validation of the model in the basin can be considered satisfactory $\left(0.36<\mathrm{E}_{\mathrm{NS}}<0.75\right)$.

Figure 4 shows the main components of the water balance simulated with the SWAT model for the Galo creek watershed, from 1997 to 2003, considering the different proposed land use scenarios. The mean

Table 2. Land use and soil cover in real and simulated scenarios by SWAT model in the Galo creek watershed

\begin{tabular}{|c|c|c|c|c|c|c|c|c|}
\hline \multirow[t]{2}{*}{ Land use } & \multicolumn{2}{|c|}{$\mathrm{Co}$} & \multicolumn{2}{|c|}{ C1 } & \multicolumn{2}{|c|}{ C2 } & \multicolumn{2}{|c|}{ C3 } \\
\hline & $\mathrm{km}^{2}$ & $\%$ & $\mathrm{~km}^{2}$ & $\%$ & $\mathrm{~km}^{2}$ & $\%$ & $\mathrm{~km}^{2}$ & $\%$ \\
\hline Native forest & 534.90 & 55.0 & 749.80 & 77.10 & 943.80 & 97.00 & 4.10 & 0.40 \\
\hline Agricultural crop & 21.90 & 2.20 & 13.70 & 1.40 & 21.90 & 2.20 & 13.70 & 1.40 \\
\hline Pasture & 408.90 & 42.0 & 205.80 & 21.10 & 0.00 & 0.00 & 948.00 & 97.50 \\
\hline Urban area & 0.08 & 0.01 & 0.08 & 0.01 & 0.08 & 0.01 & 0.08 & 0.01 \\
\hline Bare soil & 6.20 & 0.60 & 2.60 & 0.20 & 6.20 & 0.60 & 6.20 & 0.60 \\
\hline
\end{tabular}

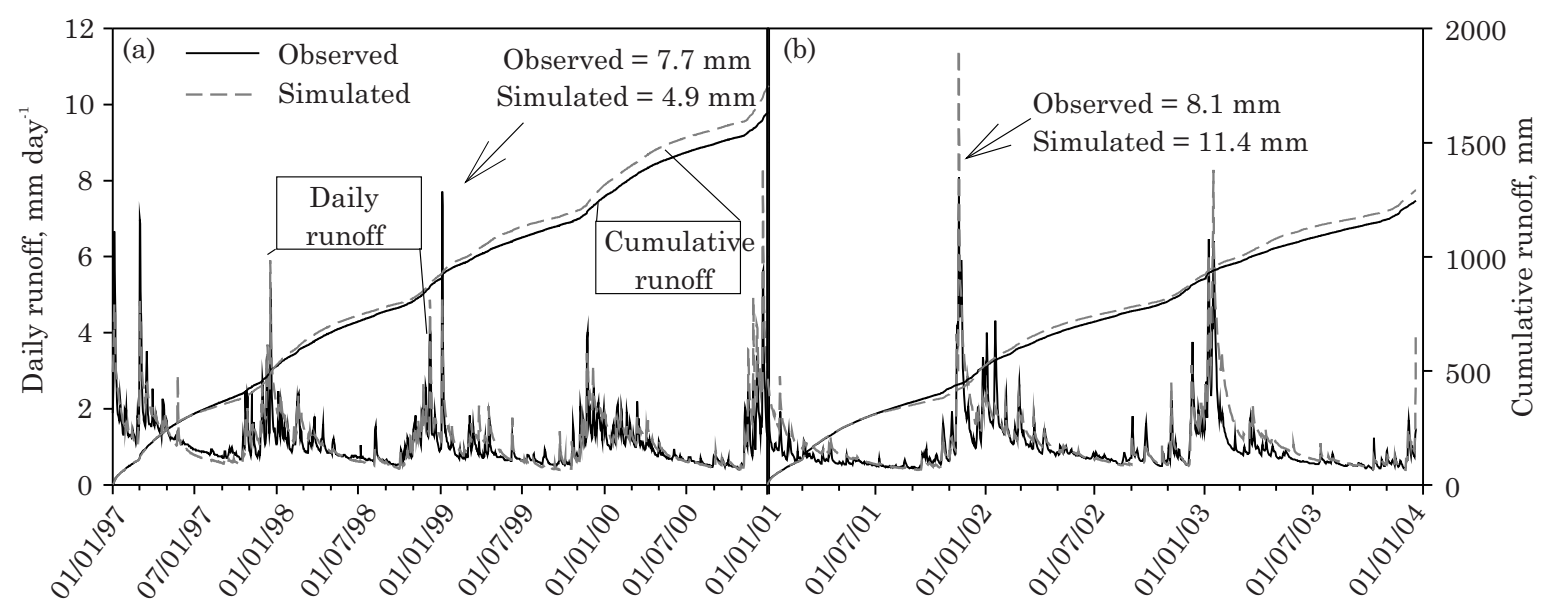

Figure 3. Hydrographs of observed and SWAT-simulated daily and cumulative runoff in the Galo creek watershed in periods (a) of calibration, from Jan. 1st, 1997 to Dec. 31, 2000, and (b) of validation, from Jan. 1st, 2001 to Dec. 20, 2003. 
Table 3. Observed and SWAT-simulated annual runoff in the Galo creek watershed during calibration and validation periods

\begin{tabular}{|c|c|c|c|c|c|c|}
\hline \multirow{2}{*}{ Period } & \multirow{2}{*}{ Year } & \multirow{2}{*}{ Precipitation } & \multicolumn{2}{|c|}{ Annual runoff } & \multirow{2}{*}{ Error } & \multirow{2}{*}{ Error } \\
\hline & & & Observed & Simulated & & \\
\hline & & & & 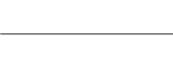 & & $\%$ \\
\hline \multirow[t]{4}{*}{ Calibration } & 1997 & 1441.0 & 519.7 & 531.2 & -11.4 & -2.2 \\
\hline & 1998 & 1203.2 & 382.5 & 402.8 & -20.3 & -5.3 \\
\hline & 1999 & 1251.3 & 360.6 & 398.7 & -38.1 & -10.6 \\
\hline & 2000 & 1272.5 & 368.6 & 442.4 & -73.8 & -20.0 \\
\hline \multirow[t]{3}{*}{ Validation } & 2001 & 1220.1 & 346.1 & 430.3 & -84.2 & -24.3 \\
\hline & 2002 & 1171.5 & 389.0 & 386.8 & 2.3 & 0.6 \\
\hline & 2003 & 1111.2 & 334.2 & 435.7 & -101.5 & -30.4 \\
\hline
\end{tabular}

Table 4. Results of linear regression of the SWAT simulation of daily runoff in the Galo creek watershed, during calibration and validation periods

\begin{tabular}{lcc}
\hline \multirow{2}{*}{ Statistical parameter } & \multicolumn{2}{c}{ Analysis period } \\
\cline { 2 - 3 } & Calibration & Validation \\
\hline Equation & $\hat{y}=1.0329 \times$ & $\hat{y}=1.1104 \mathrm{x}$ \\
Coef. of determination $\left(\mathrm{R}^{2}\right)$ & 0.91 & 0.92 \\
F test & $15708^{*}$ & $13016^{*}$ \\
Angular coef. $\left(\beta_{1}\right)$ & $1.0329^{*}$ & $1.1104^{*}$ \\
\hline
\end{tabular}

* Significant at $5 \%$.

annual runoff $\left(\mathrm{Q}_{\text {annual }}\right)$; evapotranspiration (ET); runoff $\left(\mathrm{Q}_{\text {sur }}\right)$, lateral $\left(\mathrm{Q}_{\text {lat }}\right)$ and groundwater flow $\left(\mathrm{Q}_{\mathrm{sub}}\right)$; and change in soil water storage $\left(\Delta \theta=\mathrm{SW}_{\mathrm{t}}-\mathrm{SW}_{0}\right)$, all in $\mathrm{mm}$ were simulated.

Figure 5 shows the daily runoff hydrograph and annual cumulative runoff for 1999 and 2001. The maximum and minimum daily flows decreased in scenarios $\mathrm{C} 1$ and $\mathrm{C} 2$ and increased in C3, wellevidenced in 1999 and after a precipitation event (71.2 $\mathrm{mm}$ ) in November 2001. From early 2001 until this event, the flows generated in scenarios $\mathrm{C} 1, \mathrm{C} 2$ and $\mathrm{C} 3$ were nearly identical to $\mathrm{C} 0$, as shown by the cumulative flow curve (Figure 5b). The reason was the more homogeneous rainfall distribution in this period, with minor precipitation events, resulting in less variation in SWAT- simulated surface, subsurface and groundwater flows for the different land use scenarios.

The mean values of maximum, medium and minimum annual daily flow rates for the different proposed land use scenarios, from 1997 to 2003, are shown in table 5 . Results confirmed the reduction in maximum and minimum flows in scenarios $\mathrm{C} 1$ and $\mathrm{C} 2$, with greater forest cover and increases in $\mathrm{C} 3$, with a lower percentage of forest cover in the watershed.

\section{DISCUSSION}

There are controversies about the role of forest on the water quality and quantity in a watershed. With regard to quality, the scientific consensus is greater, allowing the conclusion that the forest cover induces improvements in the related parameters. Bertossi et al. (2013) analyzed water quality parameters in watersheds covered by forest and grassland and found that the results were better in a forested watershed. However, with regard to the amount of water in the watercourse, there is controversy. A reasonable number of studies indicate a decrease in water availability in basins with more forest vegetation (Notter et al., 2007). Our results show that deforestation decreased evapotranspiration, thus increasing the water amount (flow) in rivers.

The mean annual runoff ( $Q_{\text {annual }}$ ) was $408.4 \mathrm{~mm}$ for scenario $\mathrm{C} 1$, considering the permanent preservation areas within the basin covered with Atlantic Forest. Given a mean simulated annual runoff of $433.4 \mathrm{~mm}$ for the real scenario $\mathrm{C} 0$, the preservation of the legally protected areas induced a mean annual reduction in runoff of $25 \mathrm{~mm}$, corresponding to a reduction of $5.8 \%$.

Runoff consists of the sum of the surface components $\left(\mathrm{Q}_{\text {sur }}\right)$, lateral flow $\left(\mathrm{Q}_{\text {lati }}\right)$ and groundwater flow $\left(\mathrm{Q}_{\text {sub }}\right)$, which were lower in scenario $\mathrm{C} 1$ than $\mathrm{C} 0$ (Figure 4). The reduction in surface runoff was related to lower curve number values (used by SWAT to calculate surface runoff) for the native forest due to the better soil cover and consequently, better water infiltration. The reduction in flow values was associated with increased evapotranspiration, which was $728 \mathrm{~mm}$ for $\mathrm{C} 1$ versus $704.6 \mathrm{~mm}$ for the real scenario C0, i.e., an increase of approximately $24 \mathrm{~mm}$.

The increase in evapotranspiration in the scenarios with the highest percentage of native forest is mainly due to the higher leaf area index (LAI) of this type of vegetation, increasing the tree canopy - environment gas exchange (Pereira et al., 2010). The greater soil 


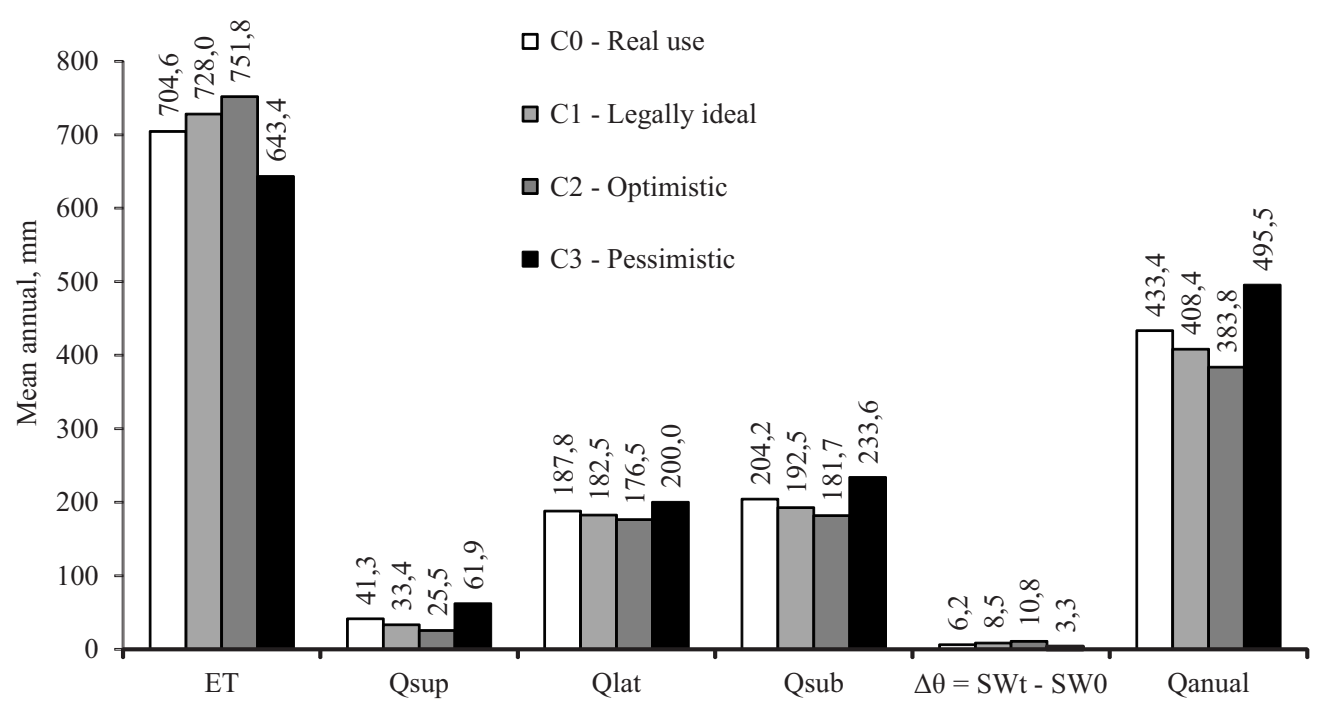

Figure 4. Evapotranspiration (ET), surface runoff $\left(Q_{\text {sur }}\right)$, lateral flow $\left(Q_{\text {lat }}\right)$, groundwater flow $\left(Q_{\text {sub }}\right)$. variation of soil water storage $\left(\Delta \theta=\mathrm{SW}_{\mathrm{t}}-\mathrm{SW}_{0}\right)$ and mean annual runoff $\left(\mathrm{Q}_{\text {annual }}\right)$, all in $\mathrm{mm}$, simulated from 1997 to 2003 , for different land use scenarios proposed in the Galo creek watershed.

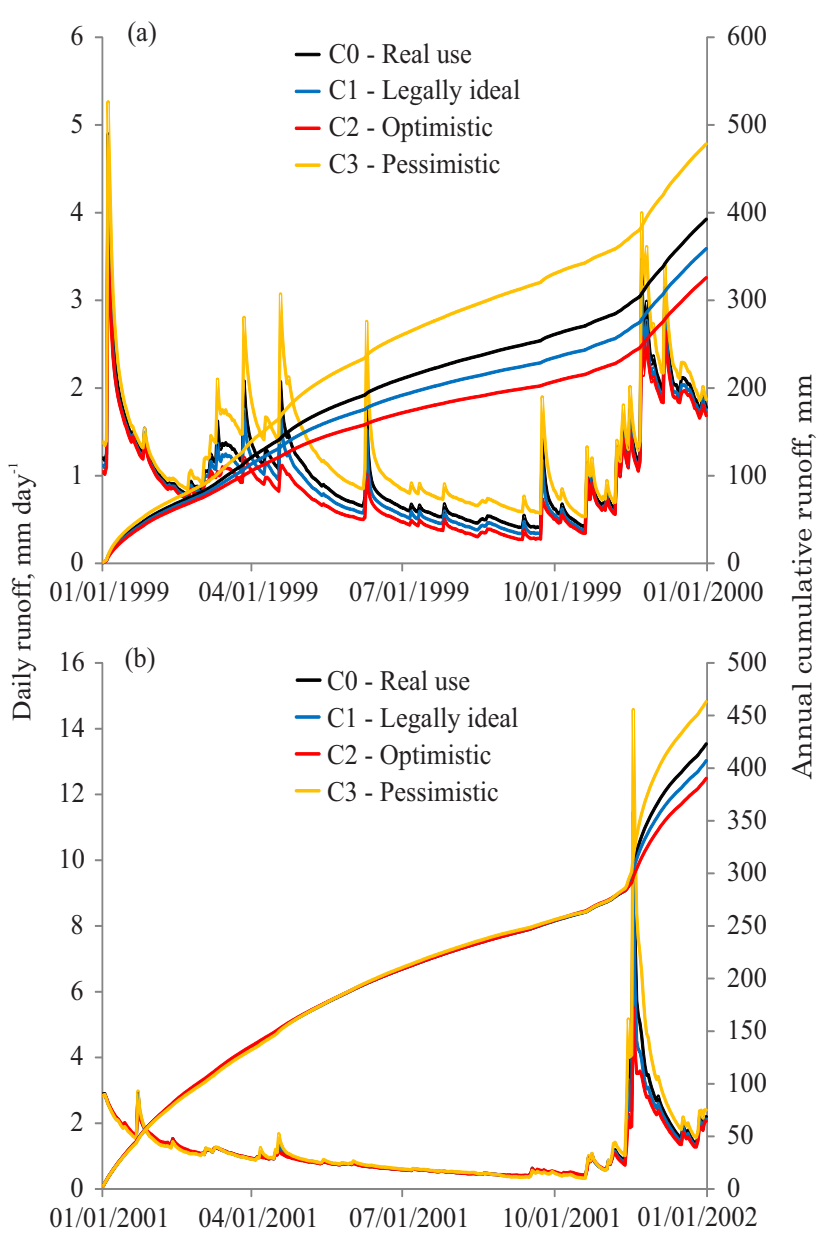

Figure 5. Hydrographs of SWAT-simulated daily and annual cumulative runoff, considering the proposed land use scenarios: (a) 1999 (calibration) and (b) 2001 (validation).
Table 5. Simulated maximum, medium and minimum daily-annual flows for different land use scenarios from 1997 to 2003

\begin{tabular}{lrrrr}
\hline \multirow{2}{*}{ Simulated flow } & \multicolumn{5}{c}{ Simulated scenario } \\
\cline { 2 - 5 } & C0 & C1 & C2 & C3 \\
\hline \multicolumn{1}{c}{$\mathrm{m}^{3} \mathrm{~s}^{-1}$} & & & & \\
Maximum & 73.2 & 66.8 & 52.0 & 82.5 \\
Medium & 12.8 & 12.0 & 11.3 & 14.6 \\
Minimum & 4.7 & 4.4 & 4.1 & 5.4 \\
\hline
\end{tabular}

volume explored by the forest roots increases water availability, resulting in higher consumption by forest vegetation. Water availability in the soil also increased with the introduction of conservation areas, as shown by the increased mean annual variation in soil water storage $(\Delta \theta)$, which was $8.5 \mathrm{~mm}$ for scenario $\mathrm{C} 1$ and $6.2 \mathrm{~mm}$ for C0 (Figure 4), contributing to an increase in evapotranspiration and reduction in annual runoff.

For scenario C2, in which $96.7 \%$ of the total basin area is covered with Atlantic forest, the model simulated a mean annual runoff reduction of $49.6 \mathrm{~mm}$ compared to the real scenario, corresponding to a percentage of $11.4 \%$, which was associated, as in scenario $\mathrm{C} 1$, to the reductions in surface, subsurface and groundwater runoff and increases in evapotranspiration and soil water storage (Figure 4). In this scenario (C2), the entire pasture area (approximately $42 \%$ ) in the basin was converted into native forest. In scenario $\mathrm{C} 1$, approximately half the area was converted. Data analysis showed a decrease of approximately $11.5 \mathrm{~mm}$ in annual runoff for every $10 \%$ of reforestation of the basin. This value was close to that obtained by von Stackelberg et al. (2007) to 
simulate the hydrologic effects of afforestation by Pinus (Pinus taeda) in the Tacuarembó river basin with the SWAT model.

For scenario C3, in which the replacement of all native forest vegetation ( $54 \%$ of the total catchment area) by grassland was simulated, the annual runoff $\left(Q_{\text {annual }}\right)$ was $495.5 \mathrm{~mm}$, or a mean increase of 62.1 $\mathrm{mm}(14.3 \%)$, compared to the real land use $(\mathrm{C} 0)$. The SWAT-simulated mean annual increase in runoff due to deforestation is in agreement with values reported in the literature (Collischonn \& Tucci, 2001). When comparing the key water balance components in basins with forest and grassland, Zhang et al. (2001) found higher values of evapotranspiration and lower values runoff in basins with a higher percentage of forest cover.

The substitution of native forest by pasture caused an opposite effect on the other hydrological scenarios. Increases of 20.5, 12.2 and $29.4 \mathrm{~mm}$, respectively, in the surface subsurface and groundwater runoff, corresponding to percentages of $49.7,6.5$ and $14.4 \%$, were observed. The model simulated a runoff increase of approximately $50 \%$, which may be responsible for the flooding of urban areas.

Despite the higher water consumption in the scenarios with a higher percentage of forest cover, due to water evapotranspiration, the soil and water conservation (Table 5) were best in these areas of the basin. Flow analysis showed that forest balanced the maximum flow and ensured minimum flow rates in the dry season, maintaining water availability in the basin and mitigating erosion processes. The vertical forest structure allowed a higher water infiltration rate into the soil, thereby reducing runoff and recharging groundwater. Furthermore, the forest cover reduced the impact of the kinetic energy of raindrops on the soil, mitigating laminar erosion.

\section{CONCLUSIONS}

1. By the parameters and procedures described in this study, the SWAT model can be used to simulate the daily flow of the Galo creek watershed with satisfactory performance.

2. Simulations in different scenarios showed that deforestation would cause a decrease in evapotranpiration ation and increase the total runoff generated in the basin. The increase in forest cover would ensure a minimum flow in the dry season and normalize the maximum flow in the flood period.

\section{LITERATURE CITED}

ALMEIDA, A.C. \& SOARES, J.V. Comparação entre uso de água em plantações de Eucalyptus grandis e Floresta Ombrófila densa (Mata Atlântica) na costa leste do Brasil. R. Árvore, 27:159-170, 2003.
ALMEIDA, A.Q.; SANTOS, A.R.; SOUZA, C.A.M. \& TULLI, L.M.A. Uso de técnicas de sensoriamento remoto na análise multitemporal do desmatamento ocorrido na microbacia do córrego do Galo, Domingos Martins, ES. R. Cient. Eletr. Eng. Flor., 14:74-88, 2009.

ANDRADE, M.A.; MELLO, C.R. \& BESKOW, S. Simulação hidrológica em uma bacia hidrográfica representativa dos Latossolos na região Alto Rio Grande, MG. R. Bras. Eng. Agríc. Amb., 17:69-76, 2013.

BERTOSSI, A.P.A.; CECÍLIO, R.A.; NEVES, M.A. \& GARCIA, G.O. Qualidade da água em microbacias hidrográficas com diferentes coberturas do solo no sul do Espírito Santo. R. Árvore, 37:107-117, 2013.

BESKOW, S.; MELLO, C.R.; NORTON, L.D. \& SILVA, A.M. Performance of a distributed semi-conceptual hydrological model under tropical watershed conditions. Catena, 86:160-171, 2011.

CONSELHO NACIONAL DO MEIO AMBIENTE - CONAMA. Resolução $\mathrm{n}^{\circ} 303$, de 20 de março de 2002. Available at: <http://www.mma.gov.br/conama/>. Accessed: Aug 10, 2012.

COLLISCHONN, W. \& TUCCI, C.E.M. Simulação hidrológica de grandes bacias. R. Bras. Recur. Hídric., 6:95-118, 2001.

DU, J.; RUI, H.; ZUO, T.; LI, Q.; ZHENG, D.; CHEN, A.; XU, Y. \& XU, C.Y. Hydrological Simulation by SWAT Model with fixed and varied parameterization approaches under land use change. Water Res. Manage., 27:2823-2838, 2013.

DURÃES, M.F.; MELLO, C.R. \& NAGHETTINI, M. Applicability of the SWAT model for hydrologic simulation in Paraopeba River Basin, MG. R. Cerne, 17:481-488, 2011.

EMPRESA BRASILEIRA DE PESQUISA AGROPECUÁRIA EMBRAPA. Centro Nacional de Pesquisas de Solos. Sistema brasileiro de classificação de solos. 2.ed. Rio de Janeiro, 2006. 306p.

FUNDAÇÃO SOs MATA ATLÂNTICA - SOS. Atlas de remanescentes florestais da Mata Atlântica: período de 1995-2000. São Paulo, 2002. 43p. (Relatório Final)

GITHUI, F.; GITAU, W.; MUTUA, F. \& BAUWENS, W. Climate change impact on SWAT simulated streamflow in western Kenya. Intern. J. Climatol., 29:1823-1834, 2009.

GREEN, C.H. \& van GRIENSVEN, A. Autocalibration in hydrologic modeling: Using SWAT2005 in small-scale watersheds. Environ. Model. Software, 23:422-434, 2008.

GUEDES, H.A.S. \& SILVA, D.D. Comparison between hydrographically conditioned digital elevation models in the morphometric characterization of watersheds. Eng. Agríc., 32:932-943, 2012.

HÖRMANN, G.; KÖPLIN, N.; CAI, Q. \& FOHRER, N. Using a simple model as a tool to parameterise the SWAT model of the Xiangxi river in China. Quatern. Intern., 208:116$120,2009$.

MELLO, C.R.; VIOLA, M.R.; NORTON, L.D.; SILVA, A.M. \& WEIMAR, F.A. Development and application of a simple hydrologic model simulation for a Brazilian headwater basin. Catena, 75:235-247, 2008

MONTEITH, J.L. Evaporation and environment. Symp. Soc. Exp. Biol., 19:205-234, 1965. 
MORAES, J.M.; SCHULER, A.E.; GUANDIQUE, M.E.G.; MILDE, L.C.; GROPPO, J.D.; MARTINELLI, L.A. \& VICTORIA, R.L. Propriedades físicas dos solos na parametrização de um modelo hidrológico. R. Bras. Recur. Hídric., 8:61-70, 2003.

NEITSCH, S.L.; ARNOLD, J.G.; KINIRY, J.R.; SRINIVASAN, R. \& WILLIAMS, J.R. Soil and water assessment tool input/output file documentation version 2005a. Available at: <http://www.brc.tamus.edu/swat/downloads/doc/ swat2005/SWAT\%202005\%20io.pdf $>$. Accessed: Jan. 11, 2010, 2004. 530p.

NEITSCH, S.L.; ARNOLD, J.G.; KINIRY, J.R. \& WILLIAMS, J.R. Soil and water assessment tool. Theoretical Documentation version 2005b. Available at: http://www.brc.tamus.edu/swat/ downloads/doc/swat2005/SWAT\%202005\%20io.pdf $>$. Accessed: Jan 11, 2010, 2005. 476p.

NEW, M.; HULME, M. \& JONES, P.D. Representing twentieth century space-time climate variability. Part 2: Development of 1901-96 monthly grids of terrestrial surface climate. J. Climate, 13:2217-2238, 2000.

NOTTER, B.; McMILLAN, L.; VIRIROLI, D.; WEINGARTNER, R. \& LINIGER, H.P. Impacts of environmental change on water resources in the Mt. Kenya region. J. Hydrol., 343:266-278, 2007.

PELUZIO, T.M.O.; SANTOS, A.R. \& FIELDER, N.C. Mapeamento de áreas de preservação permanente no ArcGIS 9.3.. Alegre, CAUFES, 2010. 58p.

PEREIRA, D.R.; MELLO, C.R.; SILVA, A.M. \& YANAGI, S.N.M. Evapotranspiration and estimation of aerodynamic and stomatal conductance in a fragment of Atlantic forest in Mantiqueira range region, MG. R. Cerne, 1:32-40, 2010.

PIRES, G.F. \& COSTA, M.H. Deforestation causes different sub-regional effects on the Amazon bioclimatic equilibrium. Geophys. Res. Lett., 40:1-6, 2013.

RADAMBRASIL. RADAR NA AMAZÔNIA. Levantamento de Recursos Naturais: Folhas SF-23/24 Rio de Janeiro/ Vitória, Geologia, geomorfologia, pedologia, vegetação e uso potencial da terra. Rio de Janeiro, Ministério das Minas e Energia, 1983. v.32, 780p.
SÁ, T.D.A.; COSTA, J.P.R. \& ROBERTS, J.M. Forest and pasture conductances in southern Pará, Amazonia. In: GASH, J.H.C.; NOBRE, C.A.; ROBERTS, J.M. \& VICTORIA, R.L., eds. Amazonian deforestation and climate. Chichester, John Wiley \& Sons, 1996. p.241-264.

SARAIVA, I.; FERNANDES, W. \& NAGHETTINI, M. Simulação hidrológica mensal em bacias sem monitoramento fluviométrico. R. Bras. Recur. Hídric., 16:115-125, 2011.

SEXTON, A.M.; SADEGHI, A.M.; ZHANG X.; SRINIVASAN, R. \& SHIRMOHAMMADI, A. Using NEXRAD and raingauge precipitation data for hydrologic calibration of SWAT in northeastern watershed. Trans. Am. Soc. Agric. Biol. Eng., 5:1501-1510, 2010.

van LIEW, M.W.; VEITH, T.L.; BOSCH, D.D. \& ARNOLD, J.G. Suitability of SWAT for the Conservation effects assessment project: A comparison on USDA - ARS watersheds. J. Hydrol. Eng., 12:173-189, 2007.

VIOLA, M.R.; MELLO, C.R.; ACERBI JR, F.W. \& SILVA, A.M. Modelagem hidrológica na bacia hidrográfica do Rio Aiuruoca, MG. R. Bras. Eng. Agríc. Amb., 13:581-590, 2009.

von STACKELBERG, N.O.; CHESCHEIR, G.M.; SKAGGS, R.W. \& AMATYA, D.M. Simulation of the hydrologic effects of afforestation in the Tacuarembó River Basin, Uruguay. Trans. Am. Soc. Agric. Biol. Eng., 50:455-468, 2007.

YUAN, Y.; BINGER, R.L.; LOCKE, M.A.; THEURER, F.D. \& STAFFORD, J. Assessment of subsurface drainage management practices to reduces nitrogen loadings using AnnAGNPS. Appl. Eng. Agríc., 27:335-344, 2011.

ZHANG, L.; DAWES, W.R. \& WALKER, G.R. Response of mean annual evapotranspiration to vegetation changes at catchment scale. Water Res. Resour., 37:701-708, 2001.

ZONTA, J.H.; MARTINEZ, M.A.; PRUSKI, F.F.; SILVA, D.D. \& MONTEBELLER, C.A. Adequação dos parâmetros do modelo de Green-Ampt-Mein-Larson em condições de campo. R. Bras. Eng. Agríc. Amb., 14:1021-1029, 2010. 